\title{
Vale expandido: contrabando negreiro e a construção de uma dinâmica política nacional no Império do Brasil ${ }^{1}$
}

Expanded Valley: Illegal Slave Trade and the making of national political dynamics in the Brazilian Empire

\author{
Tâmis Parron, Alain El Youssef, \\ Bruno Fabris Estefanes \\ Doutorandos em História Social \\ do Departamento de História da \\ Universidade de São Paulo (FFLCH/ \\ USP - São Paulo/Brasil). \\ e-mails: tamisparron@yahoo.com; \\ alayoussef@yahoo.com.br; \\ bfestefanes@yahoo.com.br
}

1

Este artigo não existiria sem as estimulantes discussões realizadas no âmbito do grupo de estudos "Império Expandido", constituido por alunos de pós-graduação do Departamento de História da FFLCH-USP. Sua primeira versão foi apresentada no seminário "O Vale e a Bacia do Paraíba no Longo Século XIX", que ocorreu em Vassouras em 24 e 25 de novembro de 2012, sob organização de Ricardo Salles, Rafael Marquese e Mariana Muaze. 0 evento fez parte das atividades do projeto "O Vale do Paraiba no século XIX e nas primeiras décadas da república", financiado pelo Pronem - Faperj/CNPO. Agradecemos em particular à leitura de André Nicacio Lima, Felipe Landim, Luiz Fernando Saraiva, Ivana Stolze Lima, Leonardo Marques, Marcelo Ferraro, Marco Holtz, Ricardo Salles e Waldomiro Lourenço da Silva.

\begin{abstract}
Resumo
0 artigo analisa as conexões entre Estado e sociedade no Império do Brasil examinando a correlação, nas décadas de 1830 e 1840, da defesa do contrabando negreiro com a montagem de um quadro político-eleitoral em nível nacional. Em sua primeira parte, revisita estudos clássicos ainda influentes na agenda de pesquisa que abordaram as relações entre Estado e sociedade no Brasil imperial. Na segunda, descreve como a defesa do contrabando negreiro aproximou líderes parlamentares do centro-sul e proprietários da Bacia do Vale do Paraiba. Na terceira, sugere que os mesmos líderes parlamentares construíram um quadro político-eleitoral nacional, com fortes implicações para a feição do Estado durante o Segundo Reinado, mediante a reforma do Código de Processo Criminal. Na última, apresenta a atuação de Honório Hermeto Carneiro Leão, então presidente da província do Rio de Janeiro, na repressão das revoltas de 1842 como um momento crucial que sintetiza os processos examinados no texto.
\end{abstract}

\section{Abstract}

This essay analyses connections between State and Society in nineteenthcentury Brazil, taking as a case study the close relations between the political defense of the illegal slave trade and the making of a political-electoral structure on a national level, in the 1830s and 1840s. In its first section, it discusses studies that have approached the problem of the relations between State and Society in imperial Brazil and are still influential on the historiographical researches. Then, it points out how the political defense of the illegal slave trade cemented alliances between parliamentarian leaders of the Brazilian Center-South region and the slave-owners of the Paraiba Valley. In the third section, it suggests that those very same parliamentary leaders built up a political-electoral national structure through the reform of the Code of Criminal Procedure, whose effects upon the workings of the Brazilian State were strongly felt throughout the nineteenth century. As a conclusion, this essay presents the actions of Honório Hermeto Carneiro Leão, then provincial president of Rio de Janeiro, against the rebellions of 1842 as the epitome of the historical processes discussed above.

Palavras-chave
tráfico negreiro, política imperial, eleições, Estado, sociedade.

\section{Keywords}

slave trade, politics in Brazil, elections, State, society. 
Anais do Senado do Império do Brasil, 31/jul./1854. p. 703. Disponivel em http://www.senado.gov.br/ publicacoes/anais/asp/IP_AnaisImperio.asp.
3

Idem, p. 705.
Ora, Sr. presidente, quem não sabe que $90 \%$ dos proprietários de serra acima que cultivam café principiaram com muito menor capital, e alguns até trabalhando por seus braços, e que hoje têm fortunas colossais? [...] Que muito era pois que eu tivesse prosperado tendo começado com um capital de 50 e tantos contos, grande parte dos quais me pertencia, e pagando de resto juros mui baixos [...] Que muito era, Sr. presidente, que nestas circunstâncias, com minha economia, com a minha indústria, com a boa ordem que sempre reinou em minha casa, eu prosperasse no fim de 18 anos?

Em 28 de julho de 1854, Honório Hermeto Carneiro Leão, então visconde de Paraná e presidente do célebre Ministério da Conciliação, passou por uma situação, se não constrangedora, no mínimo delicada. D. Manuel de Assis Mascarenhas, senador pelo Rio Grande do Norte e dono de uma eloquência farpada que o notabilizara na oposição, insinuou que fosse ilegal a origem de seus bens, uma fortuna colossal acumulada em poucos anos. $\mathrm{Na}$ sessão seguinte, sem abrir flanco a boatos e especulações, o ministro respondeu que, se estivesse em outro país, resolveria tudo num bom e simples duelo. Como não se tratava de costume tropical, porém, trocou a pólvora pelo verbo e enunciou um minucioso discurso que acabou conhecido como autobiográfico. Todo detalhe era pouco, visto que ele apreciava "a honra e a fama de probidade mais do que tudo."3

A discussão no Senado foi apenas mais uma das muitas que Carneiro Leão teve de travar com os oposicionistas do gabinete de 6 de setembro de 1853, nome oficial do Ministério da Conciliação. D. Manuel, mesmo sendo um de seus mais frequentes interlocutores, não era quem mais tirava o sono do ministro. Entre os adversários de peso que colecionara nos últimos meses estavam também os antigos companheiros de província e de partido que tinham fundado o Regresso - os chamados saquaremas. Desde que aceitara assumir uma contestada política de conciliação e de reformas jurídico-eleitorais, entre elas a da lei de 3 de dezembro de 1841, um dos fundamentos do Regresso, o visconde e depois marquês de Paraná sabia que tinha uma grande parte nas feridas que iam se abrindo, após anos de convívio harmonioso, entre ele e seus amigos do Rio de Janeiro. Provavelmente tais desavenças latejavam em sua cabeça quando falou aos senadores naquele 31 de julho. 0 discurso sobre a origem de sua riqueza parece, mais do que uma resposta a Mascarenhas, uma tentativa de recriar identidade de interesses com os ex-aliados e, quiçá, trazê-los para seu lado no debate da Conciliação. Colocar-se entre os proprietários de serra acima era também delimitar uma posição clara na geografia do mapa político imperial.

Embora deputados e senadores do Império identificassem os interesses da agricultura aos do pais e às vezes, como Carneiro Leão, entroncassem sua trajetória pessoal na ampliação moderna da economia escravista, as mediações entre Estado e sociedade no século XIX vêm recebendo na historiografia brasileira abordagens concorrentes há quase oitenta anos. Entre as décadas de 1930 e 1960, antes da consolidação do sistema da pós-graduação como a principal forma de realizar pesquisas acadêmicas profissionais no país, predominaram estudos que hoje compõem o rico acervo do ensaismo interpretativo brasileiro e cujas posições básicas, cristalizando-se como tradição intelectual, informaram direta ou indiretamente as mais diferentes perspectivas das investigações posteriores. De um lado, autores que examinaram o Brasil oitocentista pelas lentes do marxismo tenderam a definir o Estado daquele tempo como o lugar do condomínio de uma classe - formada por 
4

Ver, por exemplo, PRADO JÚNIOR, Caio. Evolução política do Brasil e outros estudos. São Paulo: Companhia das Letras, 2012 (1. ed. 1933) e SODRÉ, Nelson Werneck. História da burguesia brasileira. Rio de Janeiro: Civilização Brasileira, 1964. 5

FAORO, Raymundo. Os donos do poder: formação do patronato político brasileiro, 3. ed. São Paulo: Globo, 2001. (1. ed. 1958); e, ainda que não seja realizado em bases weberianas, VIANA, Francisco José de Oliveira. Instituições políticas brasileiras. Brasilia: Senado Federal, 1999. (1. ed. 1949).
6

DAHL, Robert A., A Critique of the Ruling Elite Model. The American Political Science Review, 52: 2, 1958. p. 463; ___. Who Governs? Democracy and Power in an American City (1961). New Haven: Yale University Press, 2005. proprietários de terras, senhores de escravos e comerciantes de grosso trato que, tendo rompido os laços políticos com a metrópole, governou durante 0 periodo monárquico fazendo valer suas ideias e seus interesses na condução do país. ${ }^{4}$ De outro, estudiosos de extração diversa, em particular weberiana, localizaram na monarquia um aparelho de Estado permeável àqueles que trilhassem carreira na burocracia, mas bastante cerrado aos demais atores sociais, dos quais procurava alijar-se. ${ }^{5}$

A dicotomia entre os enquadramentos do ensaísmo brasileiro refletia uma dualidade conceitual mais ampla que também dividiu a ciência política anglo-saxã no pós-guerra em estudos que focavam sua análise ou no polo da sociedade, ou no polo do Estado. 0 antagonismo conceitual provocou um debate teórico e metodológico na academia internacional que moldou o campo da pesquisa historiográfica profissional brasileira em seus primórdios, na década de 1970, e suas consequências ainda influenciam as investigações acadêmicas em curso sobre a política imperial. Entre os inúmeros estudiosos do Brasil oitocentista que têm se formado nos últimos quarenta anos, destacam-se dois que, ao mesmo tempo, dialogaram criticamente com os debates travados no campo da ciência política internacional, não ignoraram a tradição intelectual ensaística brasileira e, dada a posição de destaque que suas obras ainda ocupam, têm impacto nas diferentes linhas de pesquisa sobre a política imperial: José Murilo de Carvalho e Ilmar Rohloff de Mattos. Apurar o entendimento dos termos que eles propuseram para a análise do Estado imperial contribui não só para situar o lugar historiográfico do presente artigo, mas também para precisar o sentido geral dos atuais estudos sobre a política nacional no Brasil oitocentista.

$\mathrm{Na}$ crise dos regimes ditatoriais e corporativistas que se seguiu à Segunda Guerra Mundial, ganhou força na ciência política norte-americana a chamada teoria politica pluralista. Seus formuladores, apoiados na experiência democrática dos Estados Unidos, presumiam que o processo de tomada de decisões públicas resultava de contínuas negociações entre grupos movidos por interesses colidentes e investidos de um poder de barganha relativamente equilibrado, numa dinâmica que tornava improvável a prevalência hegemônica de uns sobre outros. Em suas análises eram centrais duas noções complementares. De um lado, os grupos econômicos, mesmo os mais poderosos, eram caracterizados como politicamente incoesos. De outro, as fontes de poder necessárias à atuação dos grupos sociais eram entendidas como se fossem distribuídas com relativa simetria pelo conjunto da sociedade. Dessa forma, os adeptos da teoria pluralista não julgaram relevante conceituar elites nem definir os postos formais do Estado para o exercício do poder. Mais fecundo que estudar o Estado era estudar o sistema político plural mais amplo no qual a participação democrática pautava a agenda pública. Como escreveu Robert Dahl, autor do influente Who Governs? (1961), a "teoria sobre elite dirigente" pode ser "um tipo de teoria quase-metafísica." Na hipótese de uma elite existir, cumpriria defini-la, delimitar suas preferências e verificar se elas realmente prevalecem no processo de tomada de decisões políticas. ${ }^{6}$

Embora um dos primeiros trabalhos a oferecer uma alternativa consciente à teoria pluralista tenha sido The Power Elite (1956), de C. Wright Mills, a redação da investida mais sistemática contra ela coube a Ralph Miliband, que publicou em 1969 The State in Capitalist Society: An Analysis of the Western System of Power. Judeu belga acossado pelos nazistas, Mili- 
MILIBAND, Ralph. The State in Capitalist Society. Nova York: Basic Books, 1969. p. 191. Há tradução para o português: 0 Estado na sociedade capitalista. Trad. de Fanny Tabak. Rio de Janeiro: Jorge Zahar, 1972. Sobre o autor, BLACKBURN Robin. Ralph Miliband, 1924-1994. New Left Review 206, jul./ago 1994, p. 15-25. band migrara para a Grã-Bretanha em 1940, onde se envolveria, na década seguinte, com a articulação da British New Left e com um dos grupos responsáveis pela criação da New Left Review. Sua desilusão com o desempenho do Labour Party na política britânica foi crucial em sua obra, inclusive em The State in Capitalist Society, livro no qual levou a sério o desafio de averiguar a existência de uma elite econômica e o modo como ela se impõe aos demais grupos ou classes sociais na formulação da agenda pública. Para tanto, Miliband definiu o que entendia por elite - a fração dominante da classe capitalista - e o que entendia por Estado, descrevendo-o como a inter-relação de cinco instâncias (aparato de governo: Executivo e Legislativo; aparato administrativo: banco central, burocracia do serviço público, empresas estatais; aparato coercivo: corporações militares e policiais; aparato judicial; e os governos subcentrais: assembleias legislativas locais). A estratégia de adotar uma concepção estreita do grupo de acumuladores de capital e uma concepção ampla dos lugares formais de poder atendia a dois objetivos simultâneos, o de realçar a influência política assimétrica de um grupo social diminuto e o de mostrar que não é preciso ocupar a maior parte do governo - nem das cinco instâncias do Estado - para induzir o processo de decisão política. Com isso, distinguiu, respectivamente, poder político de poder eleitoral e governo de Estado, confusões comuns nos trabalhos da época e até nos de hoje. A noção de que uma fração de classe exerce poder mesmo sem estar no governo o levou a uma leitura gramsciana, segundo a qual a hegemonia deixava de ser compreendida apenas como efeito das "instituições culturais," aparecendo também como consequência da ação do Estado, "um dos principais arquitetos do consenso conservador" e da "socialização política" (universalização) dos interesses peculiares a um grupo. ${ }^{7}$

The State in Capitalist Society ajudou a projetar Miliband como "o principal cientista político marxista no mundo anglófono," tornando-o um dos estudiosos mais citados em meados da década de 1970, segundo os cálculos da American Political Science Association. 0 livro, contudo, desencadeou uma azedada troca de resenhas entre o autor e Nicos Poulantzas, que se prolongou nas páginas da New Left Review de 1969 a 1976 e continuou em seus respectivos livros posteriores. Como é sabido, Poulantzas, imigrante grego que lecionava filosofia do direito na academia francesa, se envolvera com o existencialismo do grupo da revista Les Temps Modernes e se aproximara da vertente do marxismo estruturalista de Louis Althusser. Nas resenhas contra Miliband, ele colocou em destaque problemas de alto valor heurístico para a pesquisa histórica, entre os quais vale a pena mencionar dois que são inter-relacionados: o do sujeito como ator social e o da autonomia relativa do Estado frente à sociedade. Para Poulantzas, o Estado capitalista possuia uma adequação formal à reprodução expandida do capital que tornava dispensável a pesquisa do perfil social dos indivíduos ocupantes de seus postos-chave. Ao não percebê-lo, Miliband teria caído na contradição de usar um método da ciência política não-marxista para fazer uma análise pretensamente marxista, o que o levou a adotar uma concepção instrumentalista de Estado. Uma das formas de evitar o problema consistia, segundo Poulantzas, em usar a noção de "autonomia relativa do Estado": mesmo desprovido da influência direta, pessoal, volitiva, da elite capitalista (autonomia), o Estado enseja a reprodução ampliada do capital, beneficiando os acumuladores (relativa). Em suas respostas, Miliband identificou a posição de Poulantzas como "super-determinismo 
BARROW, Clyde W. The Miliband-Poulantzas Debate: An Intellectual History. In: ARONOWITZ, Stanley e BRATSIS, Peter (orgs.). State Theory Reconsidered: Paradigm Lost. MinneapolisLondres: University of Minnesota Press, p. 3. WETHERLY, Paul, BARROW, Clyde W. e BURNHAM, Peter. Class, Power and the State in Capitalist Society: Essays on Ralph Miliband. Nova York: Palgrave Macmillan, 2008. Os textos de Miliband e Poulantzas estão disponiveis nos números 58 (nov./dez 1969), 59 (jan./fev. 1970), 82 (nov//dez 1973) e 95 (jan./fev. 1976) da New Left Review e podem ser acessados no site da revista.

9

CARVALHO, José Murilo de. A construção da ordem. Teatro de sombras. Rio de Janeiro: Civilização Brasileira, 2003. p. 25.

10

Idem. p. 42.

11

Idem. p. 166, 138, 194 e 232. Essa leitura foi desenvolvida em CARVALHO, José Murilo de. Escravidão e razão nacional. In: Pontos e bordados: escritos de história e política. Belo Horizonte: Editora UFMG, 1998. p. 35-64. estruturalista" irredutível às diferenças empíricas dos regimes políticos particulares. As análises dos dois estudiosos possuíam pontos de contato - valendo-se de Gramsci, por exemplo, Poulantzas também considerou o Estado um meio importante para que uma fração da classe capitalista exercesse "papel dominante" sobre as demais e desse ao "bloco de poder" uma coesão ideológica que do contrário lhe faltaria. As acusações recíprocas e a recepção do debate, todavia, reduziram a visão do Estado em Poulantzas a um determinismo estreito e a de Miliband a um instrumentalismo vulgar. Nas palavras de um estudioso do assunto, a polêmica entre os dois "estilhaçou [a incipiente] teoria política marxista." Hoje, especialistas estão desenterrando a complexidade analítica e metodológica das obras que a polêmica entre seus dois autores ajudou a sepultar. ${ }^{8}$

0 mesmo contexto intelectual da teoria política pluralista que estimulou a publicação do livro de Miliband, bem como o debate subsequente entre ele e Poulantzas, também informou a pesquisa de doutorado que José Murilo de Carvalho defendeu em Stanford em 1974 sobre a especificidade da política brasileira oitocentista e cujos resultados foram publicados nos hoje clássicos A construção da ordem (1980) e Teatro de sombras (1988). Assim como Miliband, Carvalho rejeitou o axioma da teoria pluralista que depositava no equilíbrio dos grupos sociais o sentido do processo de tomada de decisão política e a consequente noção de que os postos formais do Estado eram irrelevantes para uma interpretação política. No início de $A$ construção da ordem, advertiu que "os estudos mais recentes que se prendem excessivamente a questões do tipo 'quem governa'" - título do livro de Dahl - deixam "de lado a natureza do próprio governo [do Estado] e o sentido da ação da elite [já que as fontes do poder são difusas]." Carvalho desenvolveu então o conceito de "elite política imperial" para designar os ocupantes dos postos políticos nacionais (deputado geral, presidente de província, ministro, senador, conselheiro), os quais, sendo "políticos," se destacavam da esfera econômica e, sendo da "elite," se distinguiam da vida local. Moldados por semelhante formação intelectual (Faculdade de Direito), percurso profissional (magistratura) e ocupação de cargos (citados acima), esses paladinos da lei conduziram com homogeneidade e coesão as grandes transformações que o Brasil sofreu durante a monarquia. ${ }^{9}$

Carvalho teve um segundo tipo de interlocutor. Pretendia corrigir os excessos do ensaismo marxista brasileiro que considerava o Estado oitocentista epifenômeno de forças sociais ou econômicas. Sua "elite política imperial," afastada das bases materiais da vida social, elegeria como plataforma a unidade nacional, o controle civil do poder e a democracia limitada dos homens livres. ${ }^{10}$ Com a escravidão, instituição máxima do mundo econômico, seu contato seria apenas de concessão circunstancial ou "tática," isto é, tolerava-a por depender dela para fechar o orçamento público: "não podiam," escreveu, "matar sua galinha dos ovos de ouro." Tão logo terminasse seu "acúmulo primitivo de poder," essa elite conduziria a nave do Estado à erradicação do cativeiro. ${ }^{11} \mathrm{~A}$ esse jogo de espera e destruição o autor chama "dialética da ambiguidade." A expressão é discutível. A relação que Carvalho descreve entre políticos nacionais e Estado não é "ambígua," uma vez que a elite é sempre definida como antiescravista. Nem "dialética," dado que o sistema escravista e o conjunto de valores das altas esferas do Estado, incompatíveis do início ao fim do Império brasileiro, aparecem como fenômenos estáticos, imutáveis no tempo. Ainda assim, alguns autores que estudam a defesa dos institutos da escravidão em- 
Respectivamente, RODRIGUES, Jaime. 0 infame comércio: propostas e experiências no final do tráfico de africanos para o Brasil, 1800-1850. Campinas, São Paulo: Editora da Unicamp/Cecult 2000, p. 25-26 e 30-31; e BLACKBURN, Robin. The American Crucible: Slavery, Emancipation and Human Rights. Londres/Nova lorque: Verso, 2011, p. 291-292.

13

CARVALHO, José Murilo de. Op. Cit. p. 51. Para estudos sobre o mercado interno nos anos setenta e oitenta, cf. LENHARO, Alcir. As tropas da moderação: 0 abastecimento da Corte na formação política do Brasil, 1808-1842. São Paulo: Símbolo, 1979; MARTINS, Roberto Borges \& MARTINS FILHO, Amilcar. Slavery in a nonexport economy: nineteenth century Minas Gerais revisited. Hispanic American Historical Review, 63:3, 1983, p. 537-568; e BROWN, Larissa. Internal commerce in a colonial economy, Rio de Janeiro and its hinterland, 1790-1822. 1986. Tese (Doutorado em História). Universidade de Virginia, Virginia. 1986. Entre as contribuições posteriores, não podem deixar de ser mencionados FRAGOSO, João Luis. Homens de grossa aventura: acumulação e hierarquia na praça mercantil do Rio de Janeiro (1790-1830). Rio de Janeiro: Arquivo Nacional, 1992; FRAGOSO, João Luis \& FERREIRA, Roberto Guedes, Tráfico de Escravos, Mercadores e Fianças Dois Bancos de Dados (despachos de escravos, passaportes e licenças). LIPHS (Laboratório Interdisciplinar de Pesquisa em História Social). Universidade Federal do Rio de Janeiro. Rio de Janeiro, 2001; e MARTINS, Roberto Borges, Minas e o tráfico de escravos no século XIX, outra vez. In: SZMRECSÁNYIE, Tamás e AMARAL LAPA, José Roberto. História econômica da Independência e do Império. São Paulo: Hucitec/Edusp/l. Oficial, 2002.

14

EVANS, Peter B., RUESCHEMER, Dietrich e SKOCPOL, Theda. Bringing the State Back In. Cambridge: Cambridge University Press, 1985; SKOCPOL, Theda, Bringing the State Back In. In: ibidem, p. 3-37 e PANITCH, Leo, The Impoverishment of State Theory. In: WETHERLY Paul, BARROW, Clyde W. e BURNHAM, Peter. Class, Power and the State in Capitalist Society. Op. Cit. p. 92 pregam a expressão "elite política imperial" ou "acumulação primitiva de poder." Os dados que apresentam dissolvem o esquema que adotam. ${ }^{12}$

Em seu diálogo com a teoria pluralista norte-americana e com o ensaísmo marxista brasileiro, Carvalho adotou dois pressupostos de análise. 0 primeiro era político. 0 modelo da teoria pluralista podia se aplicar a países "como Inglaterra e Estados Unidos," onde "o papel do Estado tendeu a ser menos relevante e, portanto, predominaram na elite política elementos oriundos dos mecanismos de representação parlamentar." Em contrapartida, "a estrutura política do Império era suficientemente simples," sendo "as decisões da política nacional" tomadas "por pessoas que ocupavam os cargos do Legislativo e do Executivo." 0 outro pressuposto era socioeconômico. Nos "países de revolução burguesa abortada," como Portugal e Brasil, onde não se formou uma classe social capaz de compor uma agenda pública amplamente aceita, "predominou o elemento burocrático." Nesse particular, o autor supõe que faltava densidade à vida social brasileira devido à ausência de um mercado interno por onde se aglutinassem setores do mundo produtivo, ainda que, antes de sua pesquisa sair na forma de livro, já houvesse estudos que corrigissem essa leitura. Com os dois pressupostos mencionados, Carvalho - apoiando-se numa noção teleológica da modernidade, atingida por alguns países paradigmáticos - procedeu à simplificação da estrutura política e à simplificação da vida socioeconômica para que seu modelo pudesse, ao mesmo tempo, concentrar poderes decisórios nas mãos da "elite política imperial" e afastar essa elite dos influxos do mundo material. ${ }^{13}$

Concebida e realizada no auge da teoria marxista do Estado, a pesquisa de José Murilo de Carvalho se desdobrou em livros quando os instrumentos heurísticos de Miliband e Poulantzas tinham sido reduzidos à caricatura do instrumentalismo e do determinismo. A publicação mais representativa da troca de paradigmas então em curso talvez seja Bringing the State Back In, que Peter Evans, Dietrich Rueschemeyer e Theda Skocpol organizaram em 1985. Tal como a pesquisa de Carvalho, o livro reagiu contra a teoria pluralista do sistema político e as abordagens marxistas por serem ambas "teimosamente centradas na sociedade," e condenou os "debates teóricos" travados na década anterior como "altamente especulativos." Não é à toa que a longa lista das pesquisas que Skocpol cita no capítulo que dá nome à obra inclui um texto de José Murilo de Carvalho. Em linhas gerais, pode-se dizer que Skocpol propôs estudar o Estado como ator dotado de racionalidade própria e capaz de reunir seus membros em torno de um conjunto de interesses socialmente autônomos. Embora assuma que "o contexto socioeconômico e sociocultural" não deve ser desprezado na análise, ela concentra seu esforço de reflexão em elencar: a. os casos em que o Estado goza de autonomia; b. os meios de que dispõe para fazê-lo (financeiros, pessoais, institucionais); e c. o poder que possui para mudar o comportamento dos atores, "em especial os economicamente dominantes." Como notou Leo Panitch em "The Impoverishment of State Theory," o livro que pleiteava ver as instituições políticas como fatores causais autônomos foi publicado "bem no momento em que o poder estrutural do capital e 0 alcance estratégico e ideológico das classes capitalistas tinham se tornado, talvez, mais plenamente visíveis do que nunca." Em que pese o paradoxo histórico, Skocpol, Evans e Rueschemeyer avalizaram o institucionalismo e o empiricismo desprovido de teoria como posturas científicas promissoras em diversas áreas das ciências humanas. ${ }^{14}$ 
MATTOS, Ilmar Rohloff de. 0 tempo saquarema: a formação do Estado imperial (1986). São Paulo: Hucitec, 2004, p. 14, 36, 37, 69 e 78. 0 modelo explicativo proposto por Mattos não tem deixado de receber reservas. Para duas apreciações opostas de sua validade, ver SALLES, Ricardo. 0 Império do Brasil no contexto do século XIX. Escravidão nacional, classe senhorial e intelectuais na formação do Estado. Almanack, Guarulhos, n. 4, 2do. sem. 2012. p. 5-45; e MARTINS, Maria Fernanda Vieira. Das racionalidades da História: o Império do Brasil em perspectiva teórica. Almanack, Op. Cit. p. 53-61.
Justamente em 1985, ano da publicação de Bringing the State Back In, Ilmar Rohloff de Mattos defendeu no Departamento de História da Faculdade de Filosofia, Letras e Ciências Humanas da Universidade de São Paulo a tese de doutorado que seria publicada no ano seguinte com o título de 0 tempo saquarema - assim como Carvalho redigira sua tese antimarxista no auge da teoria marxista do Estado, Mattos arrematou sua pesquisa marxista no auge da abordagem antimarxista do Estado. Seu livro é bem conhecido, mas o teor de seu enquadramento analítico, talvez pela filiação ao gênero estilístico do ensaísmo brasileiro, nem sempre é devidamente apreendido. Mattos examinou a construção do Estado imperial e a formação da classe senhorial como dois processos que se tornaram associados sob a "intervenção consciente e deliberada de uma determinada força social." Incorporando a historiografia então disponivel sobre o mercado interno, argumentou que essa "força social" se compôs de atores provenientes da região de agricultura mercantil-escravista, isto é, um complexo econômico integrado pelo polo açucareiro da baixada fluminense, pelos tropeiros engajados no comércio de abastecimento, pelos negociantes radicados

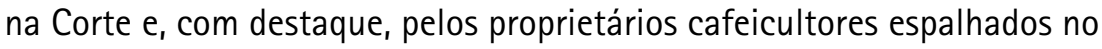
curso médio do Vale do Paraíba. E definiu os saquaremas, núcleo histórico do Partido Conservador, como o grupo político mais envolvido com a defesa dos interesses da região. ${ }^{15}$

Os debates da década de 1960 e 1970 travados no campo da teoria marxista do Estado informaram a obra de Mattos. Ao reintroduzir a escravidão na história política pela porta da frente, o autor evitou os dois extremos que estigmatizaram, de modo impreciso, as posições marxistas correntes na época: reduzir o Estado a epifenômeno instrumental da classe econômica dominante e fundar sua análise em categorias abstratas estruturalmente deterministas. Para tanto, fez duas leituras filtradas. Evitou referências textuais diretas a Miliband e Poulantzas, parecendo assimilar deles, no entanto, a importância que ambos concederam aos escritos de Gramsci como capazes de conciliar teoria, ação social e contingência conjuntural. E procedeu a uma sutil, porém crucial adaptação da matriz gramsciana ao cenário brasileiro oitocentista. 0 segundo ponto merece um comentário estendido.

É sabido que Gramsci rejeitara a classificação do Estado e da sociedade como unidades discretas da história, propondo no lugar da dicotomia o que pode ser entendido como Estado ampliado. Por essa perspectiva, a organização do Estado compreende tanto monopólios coercivos (extração do fisco, regramento da conduta, exercício da violência) como instituições ditas privadas (partidos, agremiações, imprensa, escolas), que universalizam interesses de grupos sociais específicos. 0 uso de meios repressores e suasórios para a generalização de valores particulares está na raiz da hegemonia, componente intrínseca à natureza dos Estados ampliados contemporâneos. Porque os termos de Gramsci descrevessem a fundação das democracias europeias após 1870, Mattos evitou aplicá-los à organização do Estado brasileiro que ocorreu de 1830 a meados de 1860. Tanto é assim, que o vocábulo hegemonia ocorre uma única vez em seu livro e, não por acaso, designa justamente o mundo que a burguesia criou na Europa no final do século XIX. Ao contrário do que se escreve amiúde, seu livro não contém a noção de "hegemonia saquarema," mas de "direção saquarema." 0 detalhe não é uma curiosidade lexical. Sem desprezar o papel da imprensa e da educação, Mattos sugeriu que as instituições 
16

MATTOS, Ilmar Rohloff de. Op. Cit. p. 215 e 192. A citação é a mesma que Faoro emprega para sustentar sua tese. Cf. FAORO, Raymundo. Op. Cit. p. 451-452. A leitura que Mattos fez de Gramsci se afasta da mais recorrente entre os gramscianos; tecnicamente, porém, dir-seia que ela não contradiz a obra do pensador italiano. Em um conhecido artigo, Perry Anderson demonstrou que Gramsci chegou a usar, embora não frequentemente, "direção" como sinônimo de "hegemonia"; e que, em algumas passagens dos Cadernos do Cárcere, o conceito de "hegemonia" pode até descrever o resultado do predomínio do Estado sobre a sociedade civil. Ver ANDERSON, Perry. The Antinomies of Antonio Gramsci. New Left Review, Vol. 1, n. 100, nov/dez 1976. p. 5-78. Há tradução do texto em ANDERSON, Perry; VILAS, Carlos; UDRY, Charles André et al. Crítica marxista: a estratégia revolucionária na atualidade. São Paulo: Editora Joruês, 1986. p. $7-74$.

17

SALLES, Ricardo Nostalgia imperial:a formação da identidade nacional no Brasil do Segundo Reinado. Rio de Janeiro: Topbooks, 1996; e Eo Vale era o escravo: Vassouras, século XIX. Senhores e escravos no coração do Império. Rio de Janeiro: Civilização Brasileira, 2008; DOLHNIKOFF, Miriam. 0 pacto imperial: origens do federalismo no Brasil. São Paulo: Globo, 2005; GRAHAM, Richard. Clientelismo e política no Brasil do século XIX. Rio de Janeiro: Editora UFRJ, 1997; BARMAN, Roderick J. Citizen Emperor. Pedro II and the making of Brazil. 1825-91. Stanford: Stanford University Press, 1999; e NEEDELL, Jeffrey D. The Party of Order: the Conservatives, the State, and slavery in Brazilian Monarchy. Stanford: Stanford University Press, 2006. mais capazes de universalizar valores particulares no Brasil eram a Coroa e o Estado estritamente definido: "à Coroa incumbe ainda tornar cada um dos Luzias parecido com todos os Saquaremas." Na mesma passagem, endossando a célebre frase de Joaquim Nabuco, advertiu que na monarquia "tudo se espera do Estado [...], a única associação ativa." 0 peso conferido ao aparato formal do Estado na universalização de valores e interesses não deixava de possuir precedente na historiografia brasileira e nas próprias leituras de Gramsci que Miliband e Poulantzas tinham feito. ${ }^{16}$

Nos últimos dez anos as análises da política disputada na arena nacional do Império do Brasil têm delineado um panorama eclético que em grande medida deriva ou é consequência das posições mencionadas acima. Elas avançam nas sendas abertas pelo marxismo gramsciano (Ricardo Salles, 1996 e 2008), se inscrevem no institucionalismo não-marxista (Miriam Dolhnikoff, 2005) ou adotam um empirismo desprovido de teoria que identifica as múltiplas dimensões do processo histórico com o ponto de vista dos atores estudados (Richard Graham, 1990; Roderick Barman, 1999; Jeffrey Needell, 2006). ${ }^{17} 0$ presente artigo, reconhecendo como válido 0 que há em comum às interpretações de Mattos e Carvalho, bem como à maior parte das pesquisas atuais - o Estado nacional como ator de peso nas práticas políticas do Império -, pretende revisitar algumas mediações entre a economia escravista da Bacia do Vale do Paraíba, a arquitetura institucional do Estado imperial e a dinâmica política nacional nos quadros da expansão da economia mundial na primeira metade do século XIX. Seu propósito é delinear: a. o papel do comércio negreiro transatlântico ilegal na projeção em nível nacional de um grupo de políticos da Bacia do Vale do Paraiba (chamados na historiografia de saquaremas); e b. o impacto do Estado que eles moldaram, ao aprovar a reforma do Código de Processo Criminal (lei de 3 de dezembro de 1841), sobre a nacionalização das disputas partidárias no Império do Brasil e sobre o sentido de um dos poderes previstos na Constituição de 1824, o Poder Moderador.

Ao longo de seu curso, a análise, sem pretender proceder a uma revisão exaustiva da historiografia, dialogará com as abordagens empiristas baseadas na concepção voluntarista do exercício de poder, com a leitura institucionalista do Estado e com o modelo analítico desenvolvido por José Murilo de Carvalho. Sem subscrever o entendimento que Mattos apresenta da política imperial, este artigo inscreve-se no enquadramento conceitual mais amplo que seu estudo adotou a respeito das mediações entre interesses econômicos de grupos específicos e a montagem de uma estrutura institucional abstrata, isonômica, universal. Espera-se que, ao fim da exposição, seja possivel assimilar elementos aparentemente distantes - mercado mundial, escravidão negra, Bacia do Vale do Paraiba, Código do Processo Criminal, eleições, Poder Moderador - como engrenagens de um conjunto dinâmico que começou a operar paulatinamente em meados da década de 1830 e que veio a ser objeto de sucessivas reformas na segunda metade do século XIX. A análise de seu desmanche e colapso solicita abordagem especial em outro estudo.

\section{Sociedade e Regresso}

Assim que D. Pedro I abdicou (7 de abril de 1831), um grande debate constitucional desaguou na ascensão do grupo parlamentar identificado com o padre paulista Diogo Antonio Feijó e conhecido na historiografia como "moderado." 0 clima político era emocionalmente carregado, pois estava 
18

A bibliografia sobre o assunto é extensa. Ver, entre outros, SILVA, Wlamir. Liberais e povo: a construção da hegemonia liberal-moderada na provincia de Minas Gerais (1830-1834). São Paulo: Hucitec, 2009; NEEDELL, Jeffrey D. Op. Cit.; BASILE, Marcello. O Império em construção: projetos de Brasil e ação política na Corte Imperial. 2004. Tese. (Doutorado em História Social). Instituto de Filosofia e Ciências Sociais Universidade Federal do Rio de Janeiro, Rio de Janeiro. 2004; DOLHNIKOFF, Miriam. Op. Cit.; e MOREL, Marco. O Período das Regências (18311840). Rio de Janeiro: Jorge Zahar, 2003

19

Cf. os dados disponiveis em www.slavevoyages.org.

20

Aurora Fluminense, respectivamente, 10/03 e $07 / 04 / 1834$. As referências a Wilberforce e ao movimento abolicionista inglês podem ser encontradas nas edições de 14/05/1834 da Aurora e no Jornal do Comércio de 17/01/1834, quando este encampava o projeto dos moderados em suas páginas. Para o quadro geral da imprensa moderada, cf. YOUSSEF, Alain El. Opinião pública e escravidão. Imprensa e política no Império do Brasil durante a vigência do tráfico negreiro transatlântico (1820-1853). 2010. Dissertação (Mestrado em História Social). Faculdade de Filosofia, Letras e Ciências Humanas, Universidade de São Paulo, São Paulo. p. 111-164. 2010. em jogo a possibilidade de redesenhar o Estado imperial centralista consagrado na Constituição de 1824. A feição que a monarquia devia ter - se federativa, se próxima da fórmula adotada na república norte-americana, se parecida com a da monarquia francesa - ocupou as mentes, compassou os corações e pautou os jornais da época. ${ }^{18}$

Tão relevante quanto a arquitetura do edifício imperial era, por assim dizer, o chão social em que ele se ergueria, isto é, o assunto do tráfico negreiro transatlântico. Entre as barganhas subjacentes ao reconhecimento internacional de sua independência, o Brasil tinha assinado com a Grã-Bretanha dois tratados na segunda metade da década de 1820, um comercial fixando por 15 anos suas tarifas aduaneiras a 15\% ad valorem e outro proibindo o comércio negreiro transatlântico três anos após sua ratificação (1827-1830). A Câmara dos Deputados explorou o tratado antitráfico em sua campanha contra D. Pedro I, acusando-o de ceder demais a Londres. Todavia, dado o isolamento internacional do Império no assunto, os parlamentares descriam da viabilidade de se manter o tráfico negreiro transatlântico após a convenção entrar em vigência e redigiram uma norma mais draconiana que o próprio acordo anglo-brasileiro. 0 regulamento, longe de ser uma "lei para inglês ver," conferiu o status de livres (não de libertos) aos africanos contrabandeados, previu processo criminal não apenas à tripulação dos navios apreendidos, mas a todos aqueles envolvidos no comércio (intermediários, proprietários etc.) e permitiu a qualquer indivíduo delatar desembarques ilegais às autoridades responsáveis, com direito a uma recompensa de $33 \$ 000$ por africano localizado. De 1831 a 1834, os indices do comércio negreiro transatlântico para o Brasil bateram em seu nivel histórico mais baixo desde o final do século XVII. ${ }^{19}$

A lei de 7 de novembro de 1831 criou o enquadramento institucional para as ações e para o discurso dos parlamentares e publicistas brasileiros no problema do tráfico negreiro transatlântico. Um caso notável é o de Evaristo Ferreira da Veiga. Arauto dos moderados na imprensa do Rio de Janeiro, Veiga se convenceu de que "o principal meio a se empregar, para obter a efetiva abolição do tráfico, é a persuasão" e se pôs a pregar nas páginas de sua Aurora Fluminense os lugares-comuns do antiescravismo britânico. Ele entendia que o comércio de africanos representava grande risco para a estabilidade social do país, uma vez que o tornava um "barril de pólvora" em contato com o facho da revolta escrava. 0 papel da lei de 7 de novembro na formulação de seu discurso terrificante e quase-paranóico é decisivo: "ficando ladinos, e sabendo que têm a lei por si, [os africanos importados ilegalmente] podem e hão de para o futuro demandá-[la], ou mesmo, para obterem a sua liberdade, recorrerão a meios que ameacem a tranquilidade do pais, as propriedades, e que até comprometam a obediência do restante da escravatura." Os artigos de Evaristo da Veiga foram acompanhados de perto por decisões contrárias ao tráfico tomadas pela principal agremiação civil da época, a Sociedade Defensora da Liberdade e Independência Nacional. Seus membros chegaram a abrir em 1834 um concurso para premiar quem apresentasse "a melhor memória analítica acerca do odioso tráfico de escravos africanos." 20

Ocupando posições estratégicas no governo, Diogo Antonio Feijó pôde reduzir a atos administrativos a palavra antiescravista posta em circulação na imprensa da Corte. Como ministro da Justiça, o padre paulista mandou distribuir cartazes com as multas e as penas estipuladas pela lei de 7 de novembro de 1831, a fim de estimular os delatores e inibir os contra- 
21

A distribuição de cartazes está em CONRAD, Robert. Tumbeiros: o tráfico escravista para o Brasil. São Paulo: Brasiliense, 1985. p. 95. A tentativa de acordo com Portugal, em MARQUES, João Pedro. Os sons do silêncio: o Portugal de oitocentos e a abolição do tráfico de escravos. Lisboa: Imprensa de Ciências Sociais, 1999. p. 242-243. Sobre o envio de Barbacena a Londres, BETHELL, Leslie. A abolição do comércio brasileiro de escravos: a Grã-Bretanha, o Brasil e a questão do comércio de escravos, 1807-1869. Brasilia: Senado Federal, 2002. p. 140-145; e ELLIS Jr., Alfredo. Feijó e a primeira metade do século XIX (1940). São Paulo: Cia. Editora Nacional do Livro, 1980. p. 224-229. Ver também RODRIGUES, Jaime. Op. Cit. p. 142-164, sobre a ineficácia dos juizes de paz para a supressão do contrabando. ventores. E redigiu despachos aos juizes de paz solicitando-Ihes bons olhos de ver e bons ouvidos de ouvir no cerco à clandestinidade. Ao vencer as eleições para o cargo de regente, tentou firmar com o governo português um instrumento de cooperação bilateral para o combate do contrabando negreiro. $E$, por causa dos desfalques que as tarifas aduaneiras rebaixadas a $15 \%$ ad valorem abriam no orçamento imperial, enviou o marquês de Barbacena, autor da lei de 7 de novembro de 1831, a Londres numa missão especial para rediscutir com os britânicos o conjunto das barganhas negociadas por ocasião do reconhecimento internacional da Independência brasileira. Barbacena devia solicitar a revisão para cima dos direitos de entrada no Brasil e oferecer em troca um acordo antitráfico mais severo que o vigente. Segundo instruções de Feijó, o marquês empregaria "todos os meios a seu alcance [...] para que se possa mais efetivamente reprimir no mar o tráfico de africanos." 21

A despeito do esforço, se não de todos, ao menos dos mais proeminentes moderados ligados a Feijó na luta contra a introdução de novos africanos no Brasil, a partir de 1834 se tornou cada vez mais acentuada na Bacia do Vale do Paraíba a tendência à rearticulação do comércio negreiro sob a forma de contrabando em escala sistêmica. 0 empenho de Feijó e seus aliados mostra, na realidade, que não bastava assumir o governo ( $\mathrm{Po}$ der Executivo) para abafar a pressão escravista pela reabertura do infame comércio. Era preciso engajar diversas instâncias do Estado e diferentes grupos sociais em unissono. Mas o arco de alianças que torna concebivel e realizável uma ação eficaz do Estado dependia da atuação de atores locais (políticos, membros da burocracia, homens de grosso trato e proprietários de escravos) e das tendências dos processos globais que o próprio Estado brasileiro - que dizer então do governo - não tinha condições de controlar.

No plano externo, a reorganização mundial do comércio após o Congresso de Viena ocasionou uma guerra fiscal entre os Estados Unidos e a Grã-Bretanha que, indiretamente, repercutiu nos interesses escravistas do Vale do Paraiba. Na república norte-americana, grupos manufatureiros do Norte que desejavam fechar o mercado doméstico à Grã-Bretanha suscitaram uma grande oposição do Sul livre-cambista na década de 1820, produzindo no Congresso anos de disputas tarifárias cujo desfecho teve um trágico timing com a proibição do tráfico negreiro transatlântico para o Brasil. Sob uma intensa pressão política do Sul, de 1831 a 1833 os Estados Unidos reduziram o direito de entrada sobre a libra do café de 5 centavos de dólar para 2, de 2 para 1 e, finalmente, de 1 centavo de dólar para a isenção. A tarifa alfandegária zerou em março de 1833, depois de atingir em 1831 um pico de 61\% sobre o preço da libra pago nos portos de exportação do produto. A abertura irrestrita das aduanas tornaria os Estados Unidos o maior mercado consumidor de café na economia global, o que teve efeito imediato sobre a atuação dos produtores e negociantes do Vale do Paraiba. Outro evento de magnitude no sistema internacional foi o experimento abolicionista que o Parlamento britânico iniciou com o Emancipation Act, de agosto de 1833. Além de intensificar a leitura negativa das consequências econômicas da emancipação, a lei tornou patente a alguns políticos brasileiros que, a partir dali, abolicionistas e colonos do Caribe britânico se uniriam no combate ao tráfico negreiro e à escravidão em outros espaços do continente americano. Essa frente antiescravista deveria ser contida para que o Brasil aproveitasse as oportunidades econômicas que se abriam no mercado livre do Atlântico Norte com a reformulação 
22

MAROUESE, Rafael e PARRON, Tâmis.

Internacional escravista: a política da Segunda escravidão. Topoi, Rio de Janeiro, Vol. 12, n. 23 jul/dez/2011. p. 97-117; MARQUESE, Rafael. Estados Unidos, Segunda Escravidão e a Economia Cafeeira do Império do Brasil. Almanack, n. 05, p. 51-60, Guarulhos, $1^{\circ}$ sem. 2013; e PARRON, Tâmis, Disputas locais, competições globais: a Crise da Nulificação e o mercado de café e açúcar nos Estados Unidos. $5^{\circ}$ Seminario Internacional: Cuba y la plantación esclavista - el territorio y el paisaje social. Fundación Antonio Núñez Jiménez de la Naturaleza y el Hombre \&t Historia Social Comparada Universitat Jaume I. Habana, 6/9/ nov/2013.

23

PARRON, Tâmis. A política da escravidão no Império do Brasil, 1826-1865. Rio de Janeiro: Civilização Brasileira, 2011. p. 121-178.

24

YOUSSEF, Alain El. Op. Cit. p. 165-187.

25

O Sete d'Abril, 01/08/1835

26

MARQUESE, Rafael e TOMICH, Dale. 0 Vale do Paraiba escravista e a formação do mercado mundial do café no século XIX. In: GRINBERG, Keila \& SALLES, Ricardo. O Império do Brasil (1808-1889), volume II: 1831-1870. Rio de Janeiro: Civilização Brasileira, 2009. p. 339-374. alfandegária dos Estados Unidos e com o próprio experimento abolicionista nas Antilhas britânicas. ${ }^{22}$

Os processos globais ajudam a entender por que, em 1834 e 1835, os moderados de Feijó e Evaristo sentiram no sabor de suas maiores vitórias um travo de derrota. Enquanto celebravam o Ato Adicional e a eleição de Feijó para o cargo de regente, o tráfico negreiro começou a readquirir sua antiga intensidade. No instante em que assumiu o governo, o padre paulista começou a perder o controle sobre o Estado que tinha ajudado a reformular. A ironia se torna evidente à luz da cruzada encabeçada pelo mineiro Bernardo Pereira de Vasconcelos, que, saído das fileiras moderadas, viria a capitanear na segunda metade da década o grupo conhecido por Regresso. Astuto orador, o político transformou-se no campeão do comércio de africanos no plenário da Câmara dos Deputados, acompanhado de perto por seu conterrâneo Honório Hermeto Carneiro Leão e pelos aliados fluminenses Joaquim José Rodrigues Torres e Paulino José Soares de Souza. Juntos, esses homens deram forma ao que se pode chamar de política do tráfico negreiro, cujo propósito consistia em reabrir o comércio de escravos sob a forma de contrabando em nível sistêmico escolhendo como alvo a lei de 7 de novembro de 1831. Eles elaboraram um discurso legal que previa a revogação do diploma pelo Parlamento, mas, por conta de pressões domésticas e britânicas, adotaram uma linha de atuação que, na prática, suspendeu informalmente sua aplicação. No lugar de um instrumento jurídico oficial, forjaram um procedimento político oficioso. Seus efeitos não foram pequenos. ${ }^{23}$

À semelhança do que ocorrera anteriormente, a campanha que resultou na reabertura do tráfico negreiro também teve amplo desdobramento nos espaços públicos do Rio de Janeiro, sobretudo no que diz respeito à imprensa. Enquanto Vasconcelos emitia discursos no Parlamento, seu jornal, $O$ Sete $d^{\prime}$ Abril, publicava uma série de textos abertamente escravistas. ${ }^{24}$ Um deles, de $1^{\circ}$ de agosto de 1835 , resumiu plataforma dos regressistas, estampando com todas as letras que a escravidão "era acomodada aos nossos costumes, conveniente aos nossos interesses e incontestavelmente proveitosa aos mesmos africanos, que melhoravam de condição." Portanto, a abolição do comércio de cativos não deveria ser "objeto de lei, mas que devia se deixar ao tempo e ao progresso do país." 25

A atuação na imprensa e no Parlamento ajudou a selar os interesses dos cafeicultores e de outros atores econômicos da Bacia do Vale do Paraíba aos dos políticos do Regresso. Em meados da década de 1830, quando o Brasil se tornou o maior produtor mundial de café com uma safra anual superior a 70 mil toneladas métricas ${ }_{1}^{26}$ muitas câmaras municipais enviaram petições ao Parlamento solicitando a revogação da lei de 1831, em clara sintonia com o grupo liderado por Vasconcelos. A grande maioria das vilas peticionárias se localizava nas áreas articuladas à produção cafeeira no Vale do Paraíba: Areias, Bananal, Mangaratiba, Resende, Barra Mansa, Vassouras, Valença, Paraíba do Sul e Vila do Presídio. Quando as representações chegavam à Câmara, representantes do Regresso costumavam aproveitar o ensejo para defender a derrogação da lei de 7 de novembro de 1831, fazendo, assim, com que a notícia fosse espalhada pelos proprietários do Vale e incitasse-os a peticionarem novamente ao Parlamento. 0 grau de coesão entre regressistas e cafeicultores em particular pode ser visto no fato de uma curiosa petição da Câmara Municipal de Vila de Valença ser publicada na edição de 13 de julho de 1836 de 0 Sete d'Abril. 0 texto prometia "rebelião e formal desobediência" dos senhores em caso de cumprimento da legislação antitráfico pelo 
PARRON, Tâmis. A política da escravidão. Op. Cit 163-171; e YOUSSEF, Alain El. Op. Cit. p. 168187. Cf. O Sete d'Abril, 13/07/1836. A petição de Valença também apareceu no Jornal do Comércio de $12 / 07 / 1836$.

NEEDELL, Jeffrey D. 0p. Cit. p. 68-69.

29

FELDMAN, Ariel. Espaço público e formação do Estado nacional brasileiro: a atuação política do Padre Carapuceiro (1822 a 1852). 2012. Tese (Doutorado em História Social). Faculdade de Filosofia, Letras e Ciências Humanas, Universidade de São Paulo. p. 205-261. 2012.

30

Os dados do tráfico negreiro foram retirados de www.slavevoyages.org. Propondo outra visão do problema, Jeffrey Needell escreveu: "Alguns acusam apenas o partido reacionário pelo apoio a tal comércio [contrabando negreiro]. As estatísticas mostram, contudo, que ele começou sob Feijó e floresceu por todo o Quinquênio Liberal [1844-1848]. Os estadistas de ambos os partidos concordavam com o óbvio - sem escravidão, nada de economia". NEEDELL, Jeffrey. Op. Cit. p. 120. Tal interpretação só é sustentável se for suposto que o controle do governo coincide com o controle do Estado.
Estado nacional brasileiro. Ao publicá-la em seu jornal, Vasconcelos divulgou aos quatro cantos um projeto senhorial que delimitava, claramente, qual era o raio de ação tolerável do Estado. ${ }^{27}$

Os membros do Regresso também teceram alianças com notabilidades políticas das províncias açucareiras da Bahia e de Pernambuco. Desde pelo menos 1837, o baiano Francisco Gonçalves Martins e os pernambucanos Francisco do Rego Barros e Pedro de Araújo Lima - o último viria a se tornar regente após a renúncia de Feijó - engrossaram o coro regressista na Câmara dos Deputados ${ }_{1}^{28}$ tornando-se fundamentais para a formação de uma maioria parlamentar em prol do tráfico negreiro.

Um caso particular ilustra como os arranjos negreiros tramados na Corte reverberaram nas províncias. 0 jornalista pernambucano Miguel do Sacramento Lopes Gama, também conhecido como Padre Carapuceiro, se filiara às ideias moderadas no início da Regência, pedindo reformas constitucionais e censurando o tráfico negreiro transatlântico ilegal. A partir de 1834, Gama defendeu uma reforma do Judiciário provincial no molde das leis dos prefeitos; só por volta de 1838 aceitou uma remodelação do sistema em nível nacional como a cúpula do Regresso propusera. Nesse período, enquanto atuou no plano regional, continuou a reputar o comércio de escravos o "horrivel e vergonhoso tráfico de carne humana." Após assumir uma cadeira de deputado no Parlamento nacional em 1840, seu discurso sobre 0 assunto mudou. 0 pernambucano censurou a agressividade da política externa da Grã-Bretanha e defendeu a continuação do contrabando, ressoando o discurso do Rio de Janeiro. ${ }^{29}$ Sua trajetória ilustra uma espécie de inversão da que o modelo analítico de José Murilo de Carvalho supõe. Apenas quando foi elevado às instituições nacionais supostamente despregadas dos interesses particulares e se aproximou do que o autor chama de "elite política imperial," Lopes Gama veio a adotar uma atitude afinada com o instituto da escravidão.

As alianças entre os parlamentares do Regresso e, em especial, os atores da Bacia do Vale do Paraiba coincidiram com o aumento explosivo do volume do tráfico negreiro transatlântico para o Brasil. Se, de 1831 a 1834, entraram no país pouco mais de 46 mil cativos (média anual de 11 mil e quinhentos), apenas no ano de 1835 cerca de 37 mil africanos ingressaram de forma ilegal no pais, a grande maioria deles (30 mil) na região Sudeste, onde irrigaram o coração da economia exportadora brasileira. Em 1836, o tráfico entrou na casa dos 50 mil e aí permaneceu nos anos seguintes: pouco menos de 57 mil em 1837, quase 53 mil em 1838, cerca de 56 mil em 1839. É importante atentar para a cronologia: não foi o governo do Regresso, iniciado apenas em 19 de setembro de 1837, que reabriu o tráfico negreiro transatlântico sob a forma de contrabando sistêmico. A retomada do infame comércio começou de baixo para cima: penetrando primeiro nas instâncias inferiores da polícia e do Judiciário, passando depois às Câmaras Municipais e, por fim, chegando às Assembleias Legislativas Provinciais e ao próprio Parlamento. 0 Regresso assumiu o Executivo sendo ao mesmo tempo vetor e efeito dessa força e, uma vez aboletado no poder, definiu em favor do tráfico a posição do governo imperial, garantindo a segurança jurídica da propriedade ilegal. A ação dos regressistas, ao lado de uma guinada imperialista da diplomacia britânica a partir de 1839 que não cabe analisar neste espaço, contribuiu para que, na década seguinte, a defesa do contrabando se tornasse uma espécie de consenso suprapartidário. ${ }^{30}$ 
Definição baseada em MATTOS, Ilmar R. Op. Cit. p. 45-113; e SALLES, Ricardo. Op. Cit. p. 139-141. Ver também VALVERDE, Orlando. A fazenda de café escravocrata no Brasil. Revista Brasileira de Geografia. São Paulo, 29(1), jan./mar/1967. p. 37-81, especialmente figura 22
FIGUEIRAS Jr., Araújo. Codigo do processo do Imperio do Brasil. Rio de Janeiro: Laemmert, 1874. p. 162-231.
Em sintese, a entrada clandestina no Brasil dos africanos escravizados conformou não apenas a reprodução ampliada da agroexportação escravista por algumas décadas, provendo aos proprietários a mão de obra de que careciam para montar novas fazendas ou aumentar as antigas. Forneceu também capital político aos regressistas, ligando a trajetória de seus líderes aos interesses de uma base social bem definida na Bacia do Vale do Paraíba do Sul, aqui entendida como o complexo composto pelo norte açucareiro fluminense, pelo curso médio do Vale do Paraíba dedicado à cafeicultura, pelas linhas do mercado interno entre a Corte e o sul de Minas Gerais e pela praça mercantil do Rio de Janeiro. ${ }^{31}$ Essa união trouxe benefícios aos proprietários da região e à liderança do Regresso. Para os agentes da esfera econômica, ela conteve a pressão britânica até a destruição definitiva do tráfico negreiro transatlântico (1850), consagrou a legitimação da propriedade ilegal e garantiu a estabilidade da escravidão até a promulgação da lei do Ventre Livre (1871). Aos atores do mundo político rendeu o apoio necessário para que tocassem adiante uma concepção particular de Estado. Cumpre ver agora como um grupo gestado no interior da Bacia do Vale do Paraiba interferiu na dinâmica política de outras regiões do Brasil. Como o Vale se tornou um Vale expandido.

\section{Regresso e Estado}

De 1824 a 1841 a monarquia brasileira não possuiu um aparelho oficial capaz de controlar as eleições em nivel nacional. Como não havia justiça eleitoral, isto é, uma instância dedicada ao assunto que fosse apartada dos demais ramos administrativos do Estado, o processo de organização, apuração e supervisão do sufrágio cabia a uma série de autoridades inespecíficas. Uma das mais importantes era a polêmica figura do juiz de paz. Segundo uma lei ordinária de 1827 e o Código de Processo Criminal (1832), o juiz de paz era um cargo eleito nas paróquias que agregava funções hoje tidas como policiais (vigilância da ordem pública), pré-processuais (inquérito e exame de corpo de delito), processuais (apresentação de denúncia) e eleitorais (qualificação dos cidadãos em não-votantes, votantes e eleitores). Os parlamentares que the deram poderes tão dilatados provinham da oposição formada no I Reinado, a qual receava investidas abusivas de um Estado centralista (conforme a Carta de 1824) dirigido por um suposto tirano (D. Pedro I). Os textos legais que aprovaram ainda investiram os munícipes de poderes na nomeação dos juizes de órfãos, dos juizes municipais e dos promotores, bem como ampliaram as atribuições do júri, autorizando-o a formalizar ou a barrar aberturas de processo. ${ }^{32}$ Nessa configuração, as eleições parlamentares dependeram, em parte, da atuação do juiz de paz, blindado na paróquia contra as ordens do Executivo.

A reforma constitucional de 1834, conhecida como Ato Adicional, alterou o quadro jurídico-político que fortalecera as localidades para cercear o centro do poder. Como as próprias elites provinciais pareciam ter perdido o controle social (segundo alegavam) e eleitoral nas localidades, elas conseguiram consagrar no Ato Adicional uma fórmula que, sem deixar de tolher o governo central, esvaziou também o poder municipal. Um de seus principais aspectos foi a instituição das Assembleias Legislativas Provinciais, que tinham o poder de criar ou suprimir postos do Judiciário, à exceção do de desembargador (art. 10 ${ }^{\circ}, \$ 7^{\circ}$ ). Valendo-se do expediente, algumas províncias (São Paulo, Pernambuco, Ceará, Sergipe, Paraíba do Norte e Maranhão) transferiram atribuições do juiz de paz à figura do prefeito, cargo que 
FLORY, Thomas. Judge and jury in Imperial Brazil, 1808-1871: social control and political stability in the new State. Texas: University of Texas Press, 1981. p. 28-84 e 158-163; e DOLHNIKOFF Miriam. 0p. Cit. p. 97-100

34

FLORY, Thomas. Op. Cit. p. 28-84; e NEEDELL, Jeffrey D. Op. Cit. p. 73-116. elas mesmas inventaram e cujo ocupante era designado pelo presidente de província, o qual, mesmo sendo preposto do Executivo, agia sob consulta das Assembleias Legislativas Provinciais. Pela perspectiva local, o controle dos recursos estratégicos passava da paróquia para as províncias. 0 Ato centralizava. Na ótica da Corte, o centro tolerava que as periferias redefinissem o júri, os juizes municipais, os promotores e, encaminhando o problema do juizado de paz, regulassem a seu modo o tempo de serviço, as competências e os critérios de remoção dos prefeitos. 0 Ato fragmentava. ${ }^{33}$

De 1835 e 1841, a paulatina diversidade provincial do Judiciário deu 0 que pensar aos deputados e senadores do Império do Brasil. Durante os embates parlamentares que então se travaram, os líderes do Regresso formularam uma saída que aparentava destinar-se somente à administração racional do bem-comum. Propuseram uniformizare centralizaro aparelho judiciário, passando seu controle dos níveis local e provincial para o nacional. Em seus discursos, argumentavam que as alterações judiciais efetuadas por algumas Assembleias tornavam o país pouco administrável; e que os poderes dos juizes de paz nas províncias que os mantinham intactos impediam a aplicação imparcial da lei, pondo em risco a ordem social e a unidade territorial do pais, principalmente nos casos em que se devia julgar os implicados em revoltas regionais. Criminalidade, punição de separatistas e administração pública foram os valores substanciais de suas falas parlamentares. ${ }^{34}$

0 apoio ao contrabando negreiro também pode tê-los ajudado a fazer ser aceito o novo arcabouço institucional de um Judiciário centralizado. Como o conjunto das reformas conservadoras tinha por fim esvaziar os poderes das autoridades locais, justamente daquelas cujo consentimento tinha sido crucial para a retomada inicial do tráfico negreiro em larga escala, a defesa do infame comércio que os líderes do Regresso encamparam a partir de 1836 parece ter cumprido um papel político obscuro, o de oferecer ao eleitorado da Bacia do Vale do Paraíba e de outros enclaves de plantation do Império a fiança de que a centralização do regramento da conduta podia regrar diversas ações sociais, menos a dos envolvidos no tráfico negreiro transatlântico ilegal.

Seja como for, os efeitos práticos do projeto que os regressistas propuseram não se esgotavam na questão do contrabando nem possuiam a neutralidade que suas falas parlamentares davam a entender, como se percebe na análise das reformas propriamente ditas. Em 1840, os regressistas aprovaram uma lei de "Interpretação do Ato Adicional," com a qual modificaram o $\S 7^{\circ}$ do art. $10^{\circ}$ do Ato, proibindo que as províncias redefinissem funções de agentes previstos por lei geral (como a de 1827 e 0 Código do Processo a respeito do juiz de paz). No ano seguinte, procederam à reforma do Código de Processo Criminal, chamada na época de lei de 3 de dezembro de 1841. Resumido a seu teor central, o texto depositou as funções policiais, pré-processuais e processuais do juizado de paz - aquelas que tinham sido transferidas aos prefeitos em algumas províncias, 0 que agora era considerado irregular - para os novos cargos de delegado e de subdelegado, nomeados ou pelos presidentes de província ou, para driblar demandas das Assembleias Legislativas Provinciais, pelo governo central. Também incluiu o comissário fardado na mesa eleitoral responsável pela qualificação dos cidadãos em não-votantes, votantes e eleitores; colocou as posições da magistratura togada (promotores, juizes municipais, juízes de órfãos e juízes de direito) à mercê do bico de pena dos ministros da Justiça e do Império, que os podiam remover com relativa liberdade; e 
FIGUEIRAS Jr., Araújo. Op. Cit. p. 162-231; e GRAHAM, Richard. Clientelismo e política no Brasil do século XIX. Rio de Janeiro: Editora UFRJ, 1997. p. 82-100.

36

DOLHNIKOFF, Miriam. 0 pacto imperial, citação retirada da p. 131.

37

De todos, o único que não foi citado anteriormente é o livro de BARMAN, Roderick J. Brazil: the forging of a nation, 1798-1852. Stanford: Stanford University Press. 1988.

38

BIEBER, Judy. Power, patronage, and political violence:state building on a Brazilian frontier, 1822-1889. Nebraska: University of Nebraska Press, 1999; MOSHER, Jeffrey. Political struggle, ideology and state building: Pernambuco and the construction of Brazil, 1817-1850. Nebraska: University of Nebraska Press, 2008; CARVALHO, Marcus J. M. Os nomes da Revolução: lideranças populares na Insurreição Praieira, Recife, 1848-1849. Revista Brasileira de História. São Paulo, Vol. 23, n. 45, 2003. p. 209-238 e _e CÂMARA, Bruno Dornelas. A Rebelião Praieira. In: DUARTE DANTAS, Monica (org.) Revoltas, Motins, Revoluções: homens livres pobres e libertos no Brasil do século XIX. São Paulo: Alameda, 2011. p. 355-389. criou o cargo de chefe de polícia para cada província, que, designado pelo Executivo, deteve o controle de inúmeros postos menores, como inspetores de quarteirão, carcereiros, amanuenses, escrivães de paz, etc. ${ }^{35}$

Os regressistas tinham prometido uniformizar o Judiciário, e assim fizeram. Embora a historiografia consensualmente identifique a Interpretação do Ato Adicional e a reforma do Código de Processo Criminal como obras do Regresso, não há um único entendimento sobre o sentido que elas adquiriram no quadro institucional do Império do Brasil. José Murilo de Carvalho e llmar Rohloff de Mattos, a despeito de suas diferenças metodológicas e conceituais, partilharam a leitura de que as reformas conservadoras efetuaram uma centralização judiciária, administrativa e política que selou a unidade do pais quando as revoltas regionais ameaçavam despedaçá-lo. Essa visão, que em linhas gerais provém do próprio século XIX, foi contestada por Miriam Dolhnikoff. Em 0 pacto imperial, a historiadora definiu o Ato Adicional como um arranjo federativo que se tornou o maior fator isolado na preservação da unidade nacional brasileira e argumentou que as leis do Regresso não expressavam uma concepção particular de Estado nem "atacava[m] o cerne do pacto federativo." ${ }^{36}$ Representaram apenas uma remodelação, desejada pela virtual totalidade dos parlamentares, de um ramo específico do Estado, o Judiciário.

Correta em moderar o alcance das reformas conservadoras quanto ao Ato Adicional, a análise de Dolhnikoff subestima o fundamento social das mudanças institucionais, esvaziando as diferentes concepções de Estado dos atores do tempo e desatendendo a base econômica do processo histórico subjacente à aprovação e à manutenção das leis do Regresso. Sua leitura não leva em conta o fato de que, na ausência de uma justiça eleitoral autônoma, instituída apenas na década de 1930, o desenho do Judiciário modelava a dinâmica político-partidária no país. Isto é, se os conservadores tinham prometido uniformizar o Judiciário e assim o fizeram, os efeitos de sua ação extrapolaram em muito essa esfera específica do Estado. Dotando o governo central de centenas de cargos que podiam ser oferecidos às localidades como moeda de troca por apoio eleitoral - dentre os quais se destacavam os postos de delegado e subdelegado, que controlavam os recursos estratégicos da vida local -, a lei de 3 de dezembro de 1841 permitiu ao Executivo que atingisse influência inédita sobre o resultado dos pleitos para a Câmara dos Deputados. A primeira pesquisa a acusar isso talvez tenha sido a de Thomas Flory (1984), e suas observações ganharam desdobramentos descritivos e analíticos nos estudos focados na arena política nacional - Roderick Barman (1988 e 1999), Richard Graham (1990) e Jeffrey Needell (2006) $-{ }_{1}^{37}$ bem como nos que identificaram o impacto das nomeações do governo central sobre a dinâmica política regional - Judy Bieber (1999), Jeffrey Mosher (2008), Marcus Carvalho (2003 e 2011). ${ }^{38} \mathrm{~A}$ análise a seguir dialogará com essa linha de investigação.

Se a face mais evidente e propagandeada do Judiciário centralizado era seu papel ordenador na luta contra a anarquia regencial, os próceres do Regresso não deixaram de confessar sua importância na construção dos partidos e na condução das eleições nacionais. Uma das mais explícitas dessas defesas se encontra num pedido de demissão coletiva que o famoso Ministério de 29 de setembro de 1848 - aquele que, a partir de certo momento, abrigou a trindade saquarema - apresentou ao imperador D. Pedro II em 1851. A motivação do gesto foi a desinteligência entre a Coroa e os ministros no assunto da interferência do governo central sobre as eleições 
39

"O pedido de exoneração coletiva do Ministério de 29 de setembro de 1848". In: VIANNA, Hélio. Vultos do Império. São Paulo, Editora Nacional, 1968; p. 145-153. Assinaram o documento: visconde de Monte Alegre, Eusébio de Queirós, Joaquim José Rodrigues Torres, Paulino José Soares de Sousa, Manuel Felizardo de Souza e Melo e Manuel Vieira Tosta, em 15 de novembro de 1851. Como se sabe, os regressistas foram apodados de saquaremas a partir da década de 1840 .

40

VIANNA, Hélio, Op. Cit. p. 149. Nas palavras de Mattos, a carta apresenta um "balanço de uma proposta de direção" que "reserva ao Imperador e à Coroa posição privilegiada, porque neutra e capaz de não se deixar levar pelos sentimentos de reação ou vingança e pela política de concessões de benefícios e favores pessoais.". MATTOS, IImar Rohloff de. Op. Cit. p. 190-191. para a Câmara dos Deputados. D. Pedro desejava cercear as nomeações partidárias para cargos não políticos, possibilitadas sobretudo pela lei de 3 de dezembro de 1841. Por decoro, os signatários elogiaram em abstrato a iniciativa do Imperador: "Não fazer das mercês, dos empregos e das recompensas devidas aos servidores do Estado unicamente moeda eleitoral" era um preceito eticamente incontestável, e "ninguém possui em mais elevado grau do que Vossa Majestade Imperial verdadeiro amor da Pátria e as noções do justo e do honesto." Todavia, alegando não poder abrir mão do recurso, explicaram como entendiam a relação entre o rodízio partidário no poder, a ciranda nas nomeações para diferentes cargos públicos e a construção das fidelidades partidárias no Brasil:

\begin{abstract}
Há em todos os partidos muitos homens que os seguem, não por convicções e princípios, mas por paixão ou conveniência. Era natural que esperassem que, quando o seu subisse ao poder, os tratasse com a mesma largueza com que seus adversários tinham tratado os seus. [...] Os denominados saquaremas, sobre os quais unicamente podia apoiar-se o ministério, alguns pelo natural desejo de vingança, outros pelo de verem consolidado o domínio de suas ideias, outros por quererem recuperar as posições que ocupavam, saudavam o dia 29 de setembro de 1848 com grandes esperanças. Não faltou quem esperasse e reclamasse uma inversão nas posições oficiais igual àquela que havia feito o Ministério de 2 de Fevereiro [de 1844 , do partido liberal]. Muitos que durante essa administração e as subsequentes haviam perdido emprego e posição, as reclamavam como indenizações. [...] Se não satisfizesse essas exigências, [o ministério] descontentaria aqueles de quem unicamente podia esperar apoio e daria assim força aos seus adversários. ${ }^{39}$
\end{abstract}

Poucos historiadores deram o devido valor à carta demissionária saquarema. Hélio Vianna, que a publicou em livro, considerou-a "a primeira demonstração oficial do desejo de adoção de normas parlamentaristas no Brasil," sem desenvolver a ideia. E Ilmar Rohloff de Mattos a interpretou como uma proposta saquarema de política conciliatória. Na verdade, ela sugere ser justamente o contrário. Mesmo que dentro do mais estrito decoro, a carta demissionária rejeita a "sábia e previdente política de Vossa Majestade Imperial" de buscar uma conciliação partidária fundada na extinção das nomeações partidárias e do controle eleitoral pelo governo central. ${ }^{40}$

A defesa do sistema político-eleitoral pós-1841 não permaneceu oculta nos escaninhos da administração imperial. Quando foi combatido na década de 1850, o esquema recebeu apoio na imprensa. Num artigo de 1853 publicado no Velho Brasil, Justiniano José da Rocha mimetizou, em tom satírico, o discurso que a oposição liberal vazou depois de uma vitória eleitoral do Executivo: "nessas eleições interveio o governo [...]; houve uma completa invasão do Poder Executivo na eleição que é do povo." Mas perguntou: "0 que é o governo entre nós" no discurso da oposição? Concluiu que não eram apenas "os seis ministros e os dezoito presidentes de província," isto é, cargos previstos na Constituição, mas também "um subdelegado, um inspetor de quarteirão" etc., ou seja, postos regulados pela lei de 3 de dezembro de 1841. Era aceitável que tais cidadãos, "que estão nas posições oficiais," exercessem "cada qual a sua influência," desde que "dentro dos limites imprescritiveis da legalidade," o que excluia a força física. 0 que "o partido ministerial fez para vencer as eleições" foi "o mesmo que fez a oposição: combinou chapas, candidatos, eleitores, reuniu suas influências [nomeações], concentrou seus esforços: a diferença única é que esta foi vencida, aquele vencedor." 0 que o articulista não esclareceu é por que 0 governo central foi - e sempre tinha sido desde 1841 - triunfante nas elei- 
41

[Justiniano J. da Rocha], "A eleição e a câmara". In: 0 Velho Brasil, 2 de julho de 1853, p. 2-3. Para uma sintese das reformas conservadoras, suas relações com Justiniano e seu efeito sobre o debate político brasileiro nas décadas de 1850 e 1860, PARRON, Tâmis. 0 Império num panfleto? Justiniano e a formação do Estado no Brasil do século XIX. In: ROCHA, Justiniano José da. Ação; reação; transação e seus textos. São Paulo: Edusp (no prelo).

42

Visconde do Uruguai. Ensaio sobre o Direito administrativo. Capitulo XXX § 8. In: In: CARVALHO, José Murilo de. (org.). Visconde do Uruguai. São Paulo: Editora 34, 1999. p. 465-466.

Visconde do Uruguai. Ensaio sobre o Direito administrativo, p. 410-411. ções para a Câmara dos Deputados. A resposta veio, surpreendentemente, numa obra de doutrina jurídica. ${ }^{41}$

Em 1862, na esteira da discussão sobre as engrenagens do sistema representativo no Brasil que a política da Conciliação ajudou a despertar, Paulino José Soares de Sousa, então visconde de Uruguai, publicou seu aclamado Ensaio sobre o direito administrativo. Entre as várias questões que abordou ali e não cabem neste artigo, Paulino defendeu as implicações eleitorais da reforma judiciária que ele e seus amigos saquaremas tinham composto em 1841:

\begin{abstract}
A lei de Interpretação do Ato Adicional e a de 3 de dezembro de 1841 modificaram profundamente esse estado de coisas. Pode por meio delas ser montado um partido, mas pode também ser desmontado quando abuse. Se é o governo que monta, terá contra si, em todo império, todo o lado contrário. Abrir-se-á então uma luta vasta e larga, porque terá de se basear em princípios, e não a luta mesquinha, odienta, mais perseguidora, das localidades. E, se a opinião contrária subir ao poder, encontrará na legislação meios de governar. Se, quando o Partido Liberal dominou o poder no Ministério de 2 de fevereiro de 1844, não tivesse achado a lei de 3 de dezembro de 1841 [...] ou teria caído logo ou teria saltado por cima das leis. ${ }^{42}$
\end{abstract}

No passo, Paulino repertoriou os argumentos favoráveis ao uso político das nomeações que o governo central fazia para os postos judiciários, policiais e conexos previstos na reforma do Código de Processo Criminal: a. arrancava as disputas políticas à lógica local (o antigo "estado de coisas"), vista como medíocre, particularista, sem espírito de grandeza; b. forjavam meios institucionais para a aliança político-partidária, em nível nacional, dos diversos grupos espalhados nas províncias; c. dava à relação entre o Executivo e o Parlamento maior governabilidade; d. prevenia o uso de meios coativos e fraudulentos para a obtenção de resultados eleitorais favoráveis ao governo. 0 controle eleitoral resultante do quadro judiciário do Império não é visto como abuso, distorção do sistema. É sua parte integrante. Como escreveu Paulino, "eleição livre, parlamento independente, em linguagem parlamentar, quer dizer eleição nossa e dos nossos amigos; parlamento composto de nós e dos nossos amigos." ${ }^{43}$ É forte sua descrença na autonomia das urnas.

0 sistema que os homens do Regresso inventaram possuía um aspecto delicado e controverso, ao menos para um partido que blasonava de defensor do desenho institucional inscrito na Constituição de 1824. Depois de 1841 a oposição não conseguiu mais vencer o governo nas eleições nacionais nem ao menos construir robustas minorias no Parlamento. A roda do poder travou. Sem o rodízio, sem a crença dos que estão fora do governo em um dia assumi-lo, o Estado podia perder a capacidade de gerir, dentro de seus próprios canais, as demandas de distintos atores da sociedade, abrindo um flanco para a eclosão de revoltas politicas e sociais. Nesse quadro específico, o Poder Moderador tinha de adquirir, e adquiriu, um sentido novo. Segundo a Constituição de 1824, ele possuía uma série de competências, entre as quais a de ser acionado para resolver fricções insuperáveis entre o Legislativo e o Executivo: velaria "sobre a manutenção da independência, equilibrio e harmonia dos mais poderes políticos [Executivo, Legislativo, Judiciário]" (art. 98). Quando houvesse um impasse entre 0 gabinete e o Parlamento, restava ao Imperador demitir e renomear "livremente os ministros de Estado." Ele também podia dissolver "a Câmara dos Deputados," mas só "nos casos em que o exigir a salvação do Estado" (art. 
101, par. VI e IV, respectivamente). Os termos são claros: a troca ministerial era livre; a dissolução da Câmara, excepcional (quando "o exigir a salvação do Estado").

0 modelo institucional que os saquaremas desenharam alterou 0 sentido dos artigos 98 e 101 da Constituição imperial. Se o Moderador nomeava o ministério e os ministros encaminhavam as eleições parlamentares, então ele não atendia à sua finalidade de velar "sobre a manutenção da independência" entre os três poderes. Além disso, o fim do rodízio partidário na Câmara dos Deputados mediante eleições exigia que ele trocasse os ministros e dissolvesse a Câmara para que o novo Executivo tivesse um Parlamento de sua cor política. 0 Poder Moderador tinha de gozar uma ampla liberdade, não prevista na Constituição, para que as dissoluções fossem instrumento rotineiro de alternância partidária no poder, e não recurso de "salvação do Estado." De súbito, D. Pedro II se viu sujeito a uma restrição e a uma amplitude inéditas. Restrição porque foi prejudicado no exercício de um fim constitucional do Moderador, a preservação da independência dos três poderes. Amplitude porque usaria um recurso constitucional (a dissolução) de modo inconstitucional (pela alternância partidária e rotineira no governo). A regra pode conter exceções, mas será esta: sempre que um saquarema pede autonomia absoluta para o Poder Moderador, sub-repticiamente está pedindo autonomia absoluta para suas nomeações partidárias e para a fabricação das eleições nacionais. Numa conhecida passagem de seu livro, Ilmar Mattos afirmou que os saquaremas "forjaram a Coroa em Partido." ${ }^{44}$ Talvez fosse possivel dizer que eles, na verdade, forjaram uma Coroa para os partidos, como requeria a lei de 3 de dezembro de 1841.

0 argumento exposto nas páginas precedentes possui implicações historiográficas. A imagem de que o Estado imperial possuía um sistema eleitoral pouco aberto a pleitos competitivos por causa da oferta de cargos pode remeter à interpretação que Richard Graham elaborou em Patronage and Politics in Nineteenth-Century Brazil (1990). Nessa obra, resultado de uma cuidadosa investigação em arquivos municipais, estaduais e nacionais espalhados pelo Brasil, o historiador atribuiu o emperramento da máquina eleitoral do Império ao clientelismo, fenômeno que ele define em níveis coincidentes com os do sistema eleitoral brasileiro da época: no chão da vida local, designa a proteção social a votantes em troca do sufrágio para eleitores; no alto da política nacional, descreve a oferta de cargos públicos a eleitores em retorno de apoio a candidatos do governo. Graham é primoroso na descrição das práticas do patronato, todavia uma questão de método conduz sua leitura a uma extrapolação temerária. Evitando empregar "categorias" que "os atores históricos [...] não necessariamente reconheciam," a fim de "focalizar os significados que eles próprios deram às suas ações," concluiu da leitura das correspondências trocadas entre particulares e ocupantes de posições oficiais que o clientelismo, ubíquo no país desde o período colonial, se impôs aos atores do tempo como a principal finalidade da vida política, desbancando até os temas da construção do poder central ou da defesa de interesses econômicos particulares. No símile que emprega para esclarecer o fenômeno - "semelhante àquelas árvores altas da floresta amazônica que extraem alimento das próprias foIhas que caem" - evidencia-se a dimensão tautológica de sua definição de clientelismo, a qual desconsidera diferenças de programa partidário entre as lideranças parlamentares, o vínculo intrínseco do tripé cargos, eleições 
GRAHAM, Richard. Op. Cit. p. 22 e 299. Outro estudo que considera redes clientelistas e relações pessoais como aspectos que, herdados do Antigo Regime português, se tornaram indissociáveis da máquina governativa imperial é o de Maria Fernanda Vieira Martins, Cf. VIEIRA MARTINS, Maria Fernanda. A velha arte de governar: o Conselho de Estado no Brasil imperia Topoi, Vol. 7, n. 12, jan./jun./2006. p. 178-221. Ver também . A velha arte de governar: um estudo sobre política e elites a partir do Conselho de Estado (1842-1889). Rio de Janeiro: Arquivo Nacional, 2007
46

NEEDELL, Jeffrey. Op. Cit. p. 2, 278 e 320-321.
Et construção do Estado ao longo do século XIX e, por fim, as relações que proprietários das diversas regiões econômicas do país travaram com o Estado imperial em conjunturas políticas específicas. Não importa a feição das árvores. Juntas, elas compõem a floresta indeterminada do clientelismo. ${ }^{45}$

Segundo o argumento aqui apresentado, a oferta de cargos deve ser entendida como componente integrante da montagem de um Estado centralista sem concorrência eleitoral, e não como algo que a substitui; e a construção do sistema, mais que uma inevitabilidade imposta pela carga da herança colonial, teria sido condicionada pela distribuição assimétrica de poder material que então vigorava no pais. Em 1841, a malha centralizada do Estado se expandiu amparada na adesão dos espaços econômicos mais expressivos e dependentes do tráfico negreiro transatlântico - a Zona da Mata pernambucana, o Recôncavo baiano, mas sobretudo o Vale do Paraiba fluminense e a região de Campos dos Goytacazes - ao projeto parlamentar vitorioso de Bernardo Pereira de Vasconcelos, Carneiro Leão, Rodrigues Torres, Paulino José Soares de Sousa, Eusébio de Queirós e Araújo Lima. Parte desse conjunto conservador, por sua vez, guardou uma coerente defesa do contrabando negreiro e da lei de 3 de dezembro de 1841 como princípios que o diferenciavam, em graus variáveis, de outros grupos políticos do Império do Brasil.

A união entre a Bacia do Vale do Paraíba e o Regresso conservador foi o principal veio investigativo de 0 tempo saquarema. Mais recentemente, Jeffrey Needell desenvolveu o assunto em seu minucioso The Party of Order, uma boa sintese da história do partido conservador entre as décadas de 1830 e 1870. Uma das ideias centrais do livro é que o "regime representativo e constitucional" do Império do Brasil foi "reconstruído pelo partido reacionário entre 1837 e 1842" nos termos do que fora "esboçado na Constituição brasileira de 1824." A reorganização regressista da monarquia incluiria a noção conceitual do equilibrio entre os poderes, a Interpretação do Ato Adicional e a reforma do Código de Processo Criminal. Como identifica as múltiplas dimensões do processo histórico com perspectiva dos indivíduos que estuda - nesse particular, seu método não é diferente do de Graham -, Needell considerou plenamente constitucional o que os saquaremas fizeram e enunciaram: D. Pedro II, investido do Moderador, podia mesmo dissolver livremente a Câmara e aqueles que discordavam disso desferiam um "ataque ao papel constitucional do imperador." Baseado na opinião dos interesses escravistas dos saquaremas, o autor concluiu que a Lei do Ventre Livre, porque patrocinada pela Coroa, contraditou "o princípio do equilibrio constitucional de poderes," derramando uma herança maldita sobre o futuro do país. "Foi esse legado autoritário, estatista, mal coberto por uma fina camada de legitimação institucional, que sobreviveu à monarquia, uma presença sombria na cultura política do Brasil desde então." Em algumas passagens centrais de sua narrativa, Needell oferece antes uma paráfrase da visão saquarema da história política imperial que um exame dessa política. ${ }^{46}$

Cabe, por fim, perguntar se os deputados que o sistema de 3 de dezembro de 1841 produzia eram dotados de uma autonomia decisória que os alçava à condição de "elite política imperial," devotada antes às questões de Estado que ao meio socioeconômico que os elegeu. Em $A$ construção da ordem, José Murilo de Caralho, embora mencione variações regionais e note a importância da economia para a política, procedeu a diversos cálculos para indicar que somente de 5\% a 8\% dos deputados 


\section{7}

CARVALHO, José Murilo de. Op. Cit. p. 95-117. Num cálculo sobre composição da elite política do sul no Congresso dos Estados Unidos antes de 1861, sabidamente afinada com interesses econômicos escravistas, Vicki V. Johnson mostrou que quase $65 \%$, atuando ou não na área do direito, entretinham relações diretas com os domínios do comércio ou da agricultura. Ver JOHNSON, V. V. The Men and the Vision of the Southern Commercial Conventions, 1845-1871. Columbia: University of Missouri Press, 1992, p. 50 e ss. Carvalho reconhece que, alterados seus critérios, a categoria "economia" alcançaria 50\% entre os ministros do Império (p. 111). Na análise da amostragem dos estadistas estampados na Galeria dos Brasileiros Ilustres, obra que destaca o topo da "elite política imperial" e, portanto, o grupo supostamente menos vinculado a interesses privados, um dos autores deste artigo concluiu, mesmo sem usar inventários, que ao menos $45 \%$ deles se dedicavam também ao comércio ou à agricultura. Ver PARRON, Tâmis. A Galeria dos Brasileiros Ilustres, Sisson e a elite imperial. Disponivel em: http://www.brasiliana. usp.br/node/739. De modo semelhante, em seu levantamento prosopográfico para Minas Gerais, Luiz Fernando Saraiva demonstrou que quase a metade dos principais politicos mineiros do século XIX (48\%), muitos com projeção no Senado, nos ministérios e no Conselho de Estado, eram negociantes ou fazendeiros. Ver SARAIVA, Luiz Fernando. O império nas Minas Gerais: poder e café na Zona da Mata mineira, 1853-1893. 2008. Tese (Doutorado em História Social). Instituto de Ciência Humanas e Filosofia, Universidade Federal Fluminense, Rio de Janeiro. p. 357-364. 2008. imperiais provinham da esfera econômica (isto é, viviam como proprietários rurais ou negociantes), enquanto os que atuavam para o governo (na função de magistrados ou militares) compunham de $24 \%$ a $38 \%$ do total. Tais números corroboram sua leitura antimarxista segundo a qual o Estado imperial brasileiro era pouco penetrável às demandas do mundo econômico. Seria possivel advertir que dois fatores concorrem para essa suposta inexpressividade numérica dos agentes econômicos. Segundo os critérios de Carvalho, os atores que eram ao mesmo tempo magistrados/militares e proprietários rurais foram considerados apenas como atuantes na esfera do governo. Ademais, o corpus documental utilizado, em geral esboços biográficos encomiásticos como a Galeria dos Brasileiros Ilustres (1861), não dá ênfase às fontes de renda privada do biografado. 0 uso de inventários pos$t$-mortem dos deputados (tarefa que ainda espera por ser feita) e a revisão dos critérios de classificação da ocupação profissional poderiam gerar uma imagem bem distinta da chamada "elite política imperial." ${ }^{47}$

Outra objeção ao modelo pode ser feita em termos puramente qualitativos. Se a mercê de cargos públicos e as eleições andavam unidas no mesmo processo de construção do Estado nacional, então 0 ato de escolha dos representantes políticos nascia de um amplo consórcio entre sociedade e Estado, no qual se entrelaçavam a vida local (grandes proprietários beneficiados) e as instituições nacionais (recursos públicos). 0 sistema podia até dar autonomia ao Executivo, uma vez que a influência eleitoral redundava em bancadas mais governáveis no Parlamento. A regra, porém, valia apenas para a solução de questões pontuais dentro do prazo de uma legislatura. A renovação do Parlamento a cada quatro anos solicitava novas negociações com as localidades, novas ofertas de cargos, nova proposição de nomes aceitáveis pelos proprietários rurais. Como a Câmara era, em parte, moldada pelo próprio Executivo, o deputado, fosse magistrado ou fazendeiro, não era na verdade nem o "homem do eleitor" nem um perfil abstrato de ocupação profissional, mas sim uma criatura mista, meio local e meio geral, meio particular e meio pública, meio espontânea e meio oficial. Dessa forma, as decisões eventualmente impopulares do Parlamento podiam gerar nos círculos dos proprietários duras críticas dirigidas não apenas aos deputados ou aos eleitores que os escolheram, mas também ao próprio Executivo que os recomendara. $E_{1}$ como o Poder Moderador, enredado no sistema criado em 1841, era o primum mobile das eleições, parte dos erros podia correr também por sua conta. Todos, querendo ou não, eram corresponsáveis.

A falta de uma clara cisão entre polícia, burocracia, gabinete, eleições e Poder Moderador, além de coligar as esferas privada e pública nas corridas eleitorais, criou interpenetrações nas instâncias decisórias do governo (Parlamento, Executivo, Conselho de Estado, Poder Moderador) que, conforme a conjuntura, podiam produzir efeitos diversos, ora fragilizando o sistema como um todo, ora reforçando-o. Dois exemplos distantes no tempo ajudam a demonstrar o argumento. Na década de 1880, durante a crise aguda da escravidão no Império do Brasil, o Parlamento votou contra a legalidade do status jurídico do homem escravizado, emancipando os cativos sem indenizar os senhores. Os proprietários atingidos pela medida não inculparam apenas os eleitores ou os parlamentares eleitos; sua insatisfação atingiu as raias do Executivo e do Poder Moderador, direta ou indiretamente ligados à montagem das eleições e, portanto, da composição da Câmara. A conjuntura de 1880 aporta, então, um caso em que grande parte dos proprietários se convenceu de que havia uma corresponsabilida- 
Anais do Senado do Império do Brasil, 31 de julho de 1854, p. 703-704. Disponivel em http://www.senado.gov.br/publicacoes/anais/ asp/IP_AnaisImperio.asp. Para uma análise da trajetória de Carneiro Leão, ESTEFANES, Bruno Fabris. Conciliar o Império: o Marquês de Paraná e a política imperial (1842-1856). São Paulo: Annablume, 2013. de geral negativa no sistema. Na ótica deles, todo o conjunto, inclusive 0 trono imperial, podia vir abaixo. Na década de 1840, em contrapartida, se deu o oposto. Enquanto o Parlamento defendeu o contrabando transatlântico de escravos, as interpenetrações mencionadas acima (entre público e privado, mas também entre as instâncias decisórias do governo) fortaleceram tanto o Estado quanto os interesses escravistas, como se houvesse uma percepção de corresponsabilidade geral positiva no sistema político. A trajetória de Honório Hermeto Carneiro Leão o ilustra com clareza didática. Sua presidência na província fluminense em 1842, no ano em que mineiros e paulistas pegariam em armas contra a reforma do Código de Processo Criminal, foi a ocasião propícia para a expressão, no campo militar, da aliança que vinha se consolidando entre políticos regressistas e cafeicultores do Vale do Paraíba. Retomemos, agora, o discurso autobiográfico do marquês de Paraná a fim de desenvolver o exemplo.

\section{Os "dois Honórios" e a construção da ordem imperial saquarema} Tendo em vista o que foi exposto acima, percebe-se que Carneiro Leão tinha motivos suficientes para evocar, em 1854, a facilidade de enriquecer que tinham os "proprietários de serra acima que cultivam café." Os fazendeiros do Vale do Paraiba, separados da capital imperial pela altitude da serra do mar, só espalharam sua prosperidade pela região porque tinham se unido ao projeto regressista de ordem imperial e de reabertura do tráfico negreiro transatlântico em um volume extraordinário.

No caso de Honório, o fazendeiro era o próprio político - e vice-versa. Eram "dois Honórios" que cresceram grudados; não podem ser dissociados um do outro nem retirados do contexto do Regresso. Em termos ilustrativos, é possivel propor que a fundação de sua fazenda Lordelo, no município de Sapucaia, marcou simbolicamente o início do predomínio de seu grupo político. A propriedade surgiu em 1836, quando Vasconcelos começara a articular a defesa da escravidão e da retomada do tráfico ao programa jurídico-eleitoral dos regressistas. Em seguida, Honório, investindo pesado na compra de "novos cativos" (isto é, escravos ilegais), registrou em seu livro de contas os milheiros que acumulou a partir de 1840. Não só a fundação de sua fazenda encontra eco na ascendência dos saquaremas, mas seu sucesso econômico também:

em 1839, não colhia café algum [...], mas passei sucessivamente nos anos seguintes a colher mil e tantas arrobas, 2.000, 3.000, 4.000,6.000, 8.000, 9.000. No ano de 1850 colhi 15.000 e no ano de 185220.000 arrobas! ${ }^{48}$

Honório, sua Lordelo, seus escravos e cafezais. A primeira colheita da fazenda do político-fazendeiro se deu no ano em que a Interpretação do Ato Adicional foi aprovada na Câmara. Seguiram-se, então, safras mais bem sucedidas até atingir o ápice na virada da década de 1840 para a de 1850, quando os conservadores - destacando-se entre eles a trindade saquarema - voltaram a comandar o Executivo do pais. Apenas coincidência? A trajetória de Honório sugere justamente o contrário. Vislumbram-se nela as intrincadas relações entre coisa pública e interesses particulares; não a dicotomia entre Estado e sociedade, entre política e economia. Um indivíduo que personificava a segurança que o Estado oferecia para a multiplicação das fortunas de fazendeiros e traficantes e que, ao mesmo tempo, compunha essa base social que sustentava o arcabouço jurídico-eleitoral 
49

GARDNER, George. Viagem ao interior do Brasil. Principalmente nas províncias do Norte e nos distritos do ouro e do diamante durante os anos de 1836-1841. São Paulo/Belo Horizonte: Edusp/ Itatiaia, 1975. p. 240.
50

Documento transcrito no Jornal do Commercio, durante setembro de 1956. Periódico disponivel na Biblioteca Nacional. Seção de Periódicos, microfilme rolo PRC-SPR 1 (672). Localização indicada do documento original: Arquivo Nacional - Presidentes do Rio de Janeiro. Correspondência com o ministério do Império. Livro 2 - 1838-1842 - Sec. Administrativa. forjado pelos saquaremas, legitimando-o. Não há contradição entre 0 futuro estadista marquês de Paraná e o homo economicus Honório, que "suja as mãos" com capital amealhado de forma ilegal. Na década de 1850, após a supressão do contrabando negreiro, Honório e seus antigos companheiros tornaram-se antagonistas na arena do Parlamento. No entanto, esses desdobramentos (que só podem ser abordados em outro artigo) não diminuem a importância dele para a definição do Império saquarema, no qual se casaram tão bem as noções de monarquia, de ordem (uma determinada concepção de Estado com eleições nacionalmente influenciáveis) e de economia escravista moderna, com destaque para a produção do ouro verde, o café. Muito café, por sinal, e quanto maior o capital em café, tanto maior o capital na política.

Passando na mesma época e pelo mesmo lugar em que foi fundada a fazenda Lordelo, o viajante George Gardner registrou:

\begin{abstract}
A estrada corria quase toda paralela ao rio, através de esplêndida floresta, formada por grandes árvores, de troncos em geral direitos, por vezes sem galhos até à altura de mais de cem pés. Cavalgando, não pude deixar de sentir pesar pelo fato de que nestas regiões se cortam e queimam anualmente léguas quadradas de tais florestas para dar lugar ao plantio de café. [...] Sapucaia é uma pequena aldeia com poucas casas, de bem recente construção, que deve sua origem à proximidade de uma nova ponte, ora em construção sobre o rio. ${ }^{49}$
\end{abstract}

Para desengano do estrangeiro, a fazenda de Honório e o povoado de Sapucaia cresceriam à mesma medida que a floresta tropical minguasse. Também de forma proporcional cresceria o prestígio de Carneiro Leão, como proprietário e político, entre fazendeiros não só do lado fluminense, mas também da nascente cafeicultura no sul de Minas. Um prestígio que seria completado com sua nomeação para a presidência do Rio de Janeiro em 1842, quando a pujança do Vale do Paraíba e a "santa causa do Império" se uniram numa guerra civil pela ordem que então se figurava.

Os inimigos da ocasião eram proprietários associados ao grupo de Feijó que pegaram em armas em São Paulo e Minas Gerais para repelir as leis do Regresso, em particular a de 3 de dezembro de 1841. Ao fazê-lo, permitiram que os saquaremas expressassem, no plano militar, as relações que já vinham sendo tecidas entre seu modelo de Estado e as plantations do Vale do Paraíba. Geograficamente, o município neutro da Corte era cercado pela província fluminense; no plano simbólico, esse cinturão transformaria a província em baluarte da ordem imperial contra as duas vizinhas rebeladas. A província e seus fazendeiros, é claro. 0 aporte da cafeicultura para as forças legalistas ficou registrado em um documento que Carneiro Leão redigiu cerca de quinze dias depois do fim dos combates. Trata-se de uma lista, destinada ao ministro do Império, com os nomes dos indivíduos que deviam ser recompensados por sua participação na guerra. A importância das localidades cafeeiras aparece no prólogo do ofício:

A subscrição em Valença foi de mais de 10:000\$rs tendo concorrido para esta soma Vassouras também; igual foi a de Piraí. Em Resende, Paraiba do Sul e S. João do Príncipe promoveram-se subscrições importantes segundo as possibilidades de seus habitantes. ${ }^{50}$

Em seguida, Carneiro Leão descreveu a colaboração dos proprietários e oficiais da Guarda Nacional. Nas páginas do relatório se espalha, em ponto pequeno, a rede que unia as famílias engajadas na campanha militar e arti- 
51

De acordo com os dados fornecidos por J. Needell para a década de 1830 , a cidade do Rio tinha 254 eleitores, a região da Baixada tinha $234 \mathrm{e}$ a da serra, 100. Cf. NEEDELL, J. Op. Cit. p. 64. culadas aos regressistas já havia algum tempo. Dos cafeicultores podem ser mencionados clãs renomados como os Werneck, os Teixeira Leite e os Ribeiro de Avelar, sem contar o do visconde de Baependi, vice-presidente da província do Rio de Janeiro e proprietário de grandes tratos de terras em Valença. Eram vilas e famílias que, grosso modo, haviam peticionado pela reabertura do tráfico negreiro transatlântico. Sua cruzada comum envolvia dois atos parlamentares: militavam contra a lei de 7de novembro de 1831 e a favor da de 3 de dezembro de 1841. A zona cafeeira do Vale não era tão povoada como a do polo açucareiro fluminense, e ainda assim suas vilas forneceram aporte humano e financeiro decisivos num momento crucial para a preservação da lei de 3 de dezembro de 1841, compensando seu limitado poder eleitoral com um invejável poder político. ${ }^{51}$ Ao fim e ao cabo, a geografia da ordem imperial coincidiu com a geografia do contrabando negreiro. Sem essa superposição, crucial à vitória militar saquarema sobre os rebelados, teria sido mantida intacta a reforma do Código de Processo Criminal?

Desnecessário ressaltar a importância de Honório Hermeto para os desígnios tanto do Regresso como dos cafeicultores do Vale do Paraíba em um momento crítico da história do Império do Brasil. Em grande medida, foi durante a presidência do político-fazendeiro Carneiro Leão que se consolidou a união entre os cafeicultores e o projeto de Estado nacional defendido pelos saquaremas, sobretudo por ocasião de sua viagem pelas zonas de conflito. A iniciativa de sair da sede do governo em Niterói e subir a serra foi elogiada de imediato, contando com a cobertura de um grande periódico do Império. Na Corte ou onde quer que o Jornal do Commercio daqueles dias chegasse, a campanha pôde ser seguida entusiasticamente por meio de cartas anônimas publicadas em suas páginas, nas quais eram narradas a intrepidez do presidente, bem como as recepções calorosas que sempre o aguardavam nas vilas. Em suas andanças através do Vale do Paraíba fluminense e da Zona da Mata de Minas Gerais, Honório percorreu, em 1842 , os caminhos da economia e da política que vinham ligando a cafeicultura escravista e o grupo saquarema desde a metade da década anterior. Caminhos abertos por interesses reciprocos e cujo destino comum era um Império erguido sobre o controle do trabalho e o controle das eleições em nivel nacional - problemas, aliás, que teriam longa duração na trajetória política e social do Brasil. 